$1-1-1979$

\title{
Selected factors affecting feeder calf prices in West Virginia
}

George W. Ssekitooleko-Muyinga

John P. Kuehn

Follow this and additional works at: https://researchrepository.wvu.edu/ wv_agricultural_and_forestry_experiment_station_bulletins

\section{Digital Commons Citation}

Ssekitooleko-Muyinga, George W. and Kuehn, John P., "Selected factors affecting feeder calf prices in West Virginia" (1979). West Virginia Agricultural and Forestry Experiment Station Bulletins. 671.

https://researchrepository.wvu.edu/wv_agricultural_and_forestry_experiment_station_bulletins/568 @ WVU. It has been accepted for inclusion in West Virginia Agricultural and Forestry Experiment Station Bulletins by an authorized administrator of The Research Repository @WVU. For more information, please contact ian.harmon@mail.wvu.edu. 
Bulletin 671

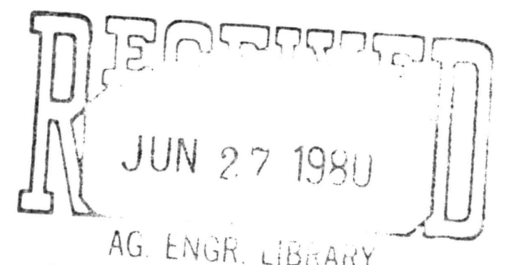

WEST VIRGINIA UNVEERSTY

June 1979

\section{Selected Factors Affecting Feeder Calf Prices \\ In West Virginia}

West Virginia University

Agricultural and Forestry

Experiment Station 
Blank Page in Original Bulletin 


\section{CONTENTS}

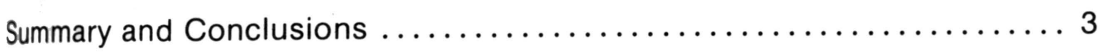

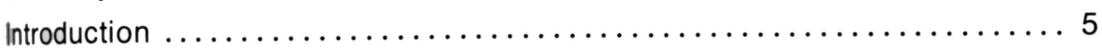

The Problem Situation and Objectives ................... 5

Source and Nature of Data $\ldots \ldots \ldots \ldots \ldots \ldots \ldots \ldots \ldots \ldots \ldots \ldots \ldots \ldots \ldots \ldots \ldots \ldots$

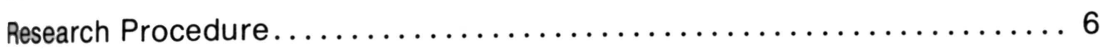

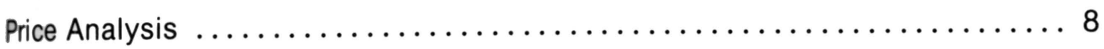

Regression Model Employed $\ldots \ldots \ldots \ldots \ldots \ldots \ldots \ldots \ldots \ldots \ldots . \ldots$

The Regression Results $\ldots \ldots \ldots \ldots \ldots \ldots \ldots \ldots \ldots \ldots \ldots \ldots$

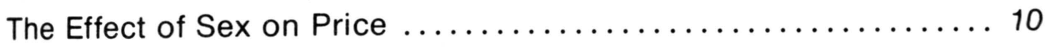

The Effect of Year on Price......................... 10

The Effect of Grade on Price ....................... 12

The Effect of the Number of Buyers on Price............. 12

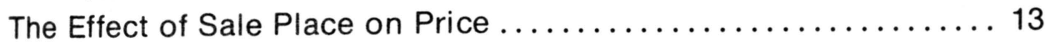

The Effect of Size of Sale on Price.................. 13

The Effect of Breed on Price ...................... 13

The Effect of Average Weight on Price ................ 14

The Effects of Date of Sale and Lot Size on Price .......... 14

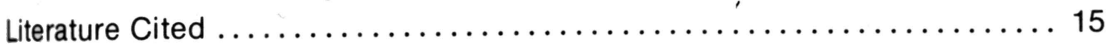

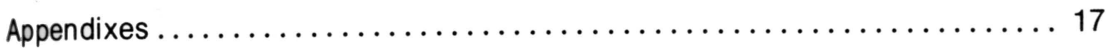




\title{
THE AUTHORS
}

G. W. M. Ssekitooleko was a Graduate Research Assistant in the Division of Resource Management at the time of this study; John P. Kuehn is Associate Agricultural Economist.

\author{
West Virginia University \\ Agricultural and Forestry Experiment Station \\ College of Agriculture and Forestry \\ Dale W. Zinn, Director \\ Morgantown
}




\section{SUMMARY AND CONCLUSIONS}

Since the 1930s, the main marketing channel for feeder calves in West Virginia has been through auction markets. In recent years, the numbers of feeder calves going through auction markets have been declining.

Various researchers have indicated that marketing problems exist for feeder calves. Most of the problems have centered around the pricing system for livestock sold at auction markets. Some farmers have only a vague idea of what they should do to improve their marketing position and income. In view of this, the pricing system of feeder calves at West Virginia auction markets was studied. The study was mainly concerned with factors which affect prices of feeder calves at auction markets, especially those factors considered to be within the control of the producers.

The overall purpose of the study was to determine the influence of selected economic and physical factors on the average price of feeder calves sold through auction markets in West Virginia. The following factors were hypothesized to affect the average price: breed, grade, the year and date of the sale, sex, sale location, average weight, lot size, size of sale, and number of buyers.

Two years' data (1976 and 1977) from ten sale places in West Virginia were used in the study. Lots were used as a basis for observation. There were 3,175 lots of animals or observations in the analysis, containing a total of 33,936 feeder calves.

Regression techniques were employed to analyze price behavior. The factors hypothesized to affect prices were included in a multiple regression equation with price as the dependent variable. The results of the analysis indicated which hypothesized factors were statistically significant. The overall explanation of the variability in price by the factors as indicated by the coefficient of determination $\left(\mathrm{R}^{2}\right)$ was 73.27 percent.

The most important factor found to influence the price was the sex of the animal. Higher prices were realized for steers than heifers and their effect on price overshadowed all other variables considered.

The second most important factor was the year the sale took place. Seasonal or yearly variations in supply and demand and, consequently, prices of feeder calves were found to be significant.

Grade had the third highest influence on price. As expected, grades "one" and "two" proved superior to grades "three," "four," and "five." The results indicated that buyers rated grade as an important factor in pricing decisions.

The next most important factor was the number of buyers present at the sale: as the number of buyers increased, the price decreased. Although this result seemingly contradicts general thinking on the effects of number of buyers on the average price paid for feeder calves, a possible explanation involves the nature of the particular buyers at the sales: Buyers consist mainly of order buyers, who are willing to pay higher prices in order to fill their quotas, and farmers, who are not usually willing to pay as high a price. Usually, there is a relatively large group of farmer-buyers and few order buyers. If this small group of order buyers is larger than usual, they could purchase the majority of the animals at a particular sale at higher prices than the farmer-buyers are willing to pay. If the small group of order buyers is smaller than usual, they might purchase what they need (at higher prices) leaving the majority of the animals at the sale to the farmers for purchase at lower prices. 
Since this explanation is only an hypothesis, the question will be examined in more detail in the future. The nature and composition of the buyers at West Virginia auctions and their effects on prices will be examined in a subsequent study.

Sale location was also found to have a significant effect on price. Some locations were found to have higher or lower prices than the average, holding all other factors considered in the model constant. This meant that farmers could go to a particular auction and receive higher prices for their animals regardless of grade, weight, sex, etc.

The size of the sale, in terms of the total number of animals sold, was the next most important factor affecting price. It was found that as the size of sale increased, average price per hundredweight decreased slightly. However, although the variable was statistically significant the association between size of sale and price was very small.

Breed was the seventh most important factor affecting price. Charolais and Angus crosses received significantly higher prices and other purebreds received significantly lower prices than the average of all breeds, assuming all other variables in the model were held constant. However, purebred Angus and Herefords accounted for almost 60 percent of the total number of animals sold, and the fact that they dominated was probably the reason they did not have statistically significant effects on price which were different from the average of all breeds.

When one factor (Hereford, for example) dominates in a dummy variable (breed) it is the major determinant of the mean. Since the model determines statistical significance based on differences between means, the dominant factor may not be significantly different statistically.

Although the effect of average weight on price was statistically significant, it was only responsible for 0.12 percent out of the 73.27 percent explained by all variables in the model. The results did indicate, however, that there was an increase in price as the average weight increased up to 508 pounds. Thereafter, the price started to decline.

Date of sale and lot size were not found to be statistically significant. In the case of lot size this lack of statistical significance may have some interesting implications: In the past, lot sizes were smaller making it difficult for order buyers to fill their trucks. In the last few years, however, lot sizes have been larger and in sizes which allow more efficient distribution. If this is the case, the differential effect of lot size on price would not be as great presently as in the past. Another consideration is that lot size is correlated with size of sale. At the larger sales, lot sizes are larger. The statistical model showed size of sale to be a more important affector of price than lot size, and as a result, lot size was not a statistically significant factor affecting price.

The present study was undertaken with only two years of data at ten auction markets. Efforts are now underway (September, 1978) to expand this information to include a longer time period and a more in-depth analysis of some of the hypothesized variables. 


\section{Selected Factors Affecting Feeder Calf Prices In West Virginia}

\section{G. W. M. Ssekitooleko and John P. Kuehn}

The present market structure of the West Virginia livestock economy had its beginnings in about 1931. Since this time feeder calves have been primarily sold through auction markets. This structure replaced the three-and four-year grass-fed steer enterprise which was the major component of livestock production prior to that time. Grass-fed steer production was experiencing difficulties because of changes in market demand. Smaller cattle were preferred that carried the desired finish at a younger age (Emch, 1967).

In 1933, 240 calves were sold in organized auction sales. Such sales continued to steadily grow throughout the years that followed. The grading of animals sold through auction markets also became more and more acceptable to both sellers and buyers. In 1966, 139,000 feeder calves were sold in West Virginia and 22,055 of these calves were sold on a graded basis.

During recent years, sales of calves through auction markets have been declining. In 1961, 104,400 calves (84 percent of the total sold) were sold through auction markets in West Virginia. In 1969, only 60,735 calves (52 percent of the total sold) were sold through such markets. This represented a decrease of 43,665 in the number of calves sold through the auction markets in the given time period (Golden and Kuehn, 1972). This decrease in itself is an indication that a problem or problems exist somewhere in the feeder calf industry, either in marketing, production, or both.

\section{The Problem Situation and Objectives}

Price behavior at West Virginia auction markets is quite vital and important to both livestock producers and buyers. Many producers have only a vague idea of prices to expect or what they can do to improve their market position. That being the case, it is important to determine the factors affecting feeder calf prices. Some of the factors considered include: average weight, grade, breed, sex, lot size, date of sale, year of sale, size of sale, and numbers of buyers. There is very little information concerning the relative importance of these factors and their effects on the price of feeder calves at auction markets in West Virginia.

The major objective of this study was to provide information which could be useful to feeder calf producers in raising the required type of calves and improve the efficiency of marketing feeder calves. This could lead to the improvement of the incomes and market positions of the producers. More specifically the objectives were:

1. To hypothesize factors which may affect the prices of feeder calves at West Virginia auction markets.

2. To evaluate the nature and extent of the influence of these factors on feeder calf prices. 


\section{Source and Nature of Data}

The data used in this study were obtained from West Virginia special feeder calf auction markets for the years 1976 and 1977. All feeder calves sold in these auction markets were represented to be sired by beef type bulls and out of good commerical cows. Approximately 55 percent were steers and 45 percent were heifers. The calves were delivered to the auctions from the farms of consignors and were individually tagged before weighing and grading. The grading was done by livestock specialists from the West Virginia Department of Agriculture and the Cooperative Extension Service. Sale sheets (Appendix A) were provided at these sales. All the information concerning each lot to be sold is recorded on these sale sheets except names of purchasers and the price per hundredweight. Both of these are filled in during the sale.

All calves were graded in accordance with United States Department of Agriculture standards for feeder cattle. The calves were separated according to breed, sex, grade, and frame size and also divided into weight groups, generally broken at 50-pound intervals. All calves were sold by the hundredweight in graded lots. The size of lot varied from less than 5 animals to 80 or more animals. The animals in each lot were, in most cases, of the same breed and grade. However, in a few cases animals of different breeds, but of the same grade, were put in one lot and sold at the same price per hundredweight. Such lots were excluded from this analysis. The remaining lots were used in the analysis as the population to be observed and studied. Lots, or observations, totaled 3,175 and contained 33,936 calves.

The sale sheets were obtained from the Cooperative Extension Specialist to whom all copies of the sale sheets and sale reports from all feeder calf auction markets in West Virginia are submitted. All the sale places were included in this study except those which did not record all of the required data and information.

Ten sale places out of the possible eighteen were used. These ten fully recorded all the data and information required for the study. Each of these ten places conducted an average of two special sales during each year. The sale places used in the study were: Petersburg, Greenbrier, Elkins, Jackson's Mill, Harrisville, Marlinton, Bridgeport, Buckhannon, Terra Alta, and Spencer (Figure 1). See Table 1 for the number of sales included in the study for each location, average number of calves sold per sale, total number of calves sold at each sale, and the percentages of the totals for location.

\section{Research Procedure}

The 1976 and 1977 feeder calf sale data and information from ten auction markets in West Virginia were coded on the data spread sheets and then punched onto computer data processing cards. One card was used for each of the 3,175 lots of calves (observations). The data and information punched on these cards included the following: code number of the sale place, breed of calves in every lot size, grade of calves, average weight, sex, lot size, number of calves sold at each sale, number of buyers at the sale, and price in dollars per hundredweight. The information was stored on a computer disc.

Since marketing information concerning individual markets is confidential, each of the ten sale places was arbitrarily assigned a code number.

The grade variables one to five were used in the analysis. The new grading system employs a numerical rating as opposed to names. Grade "one" represents a better grade than "two" or "five." At a few sale places, the old 


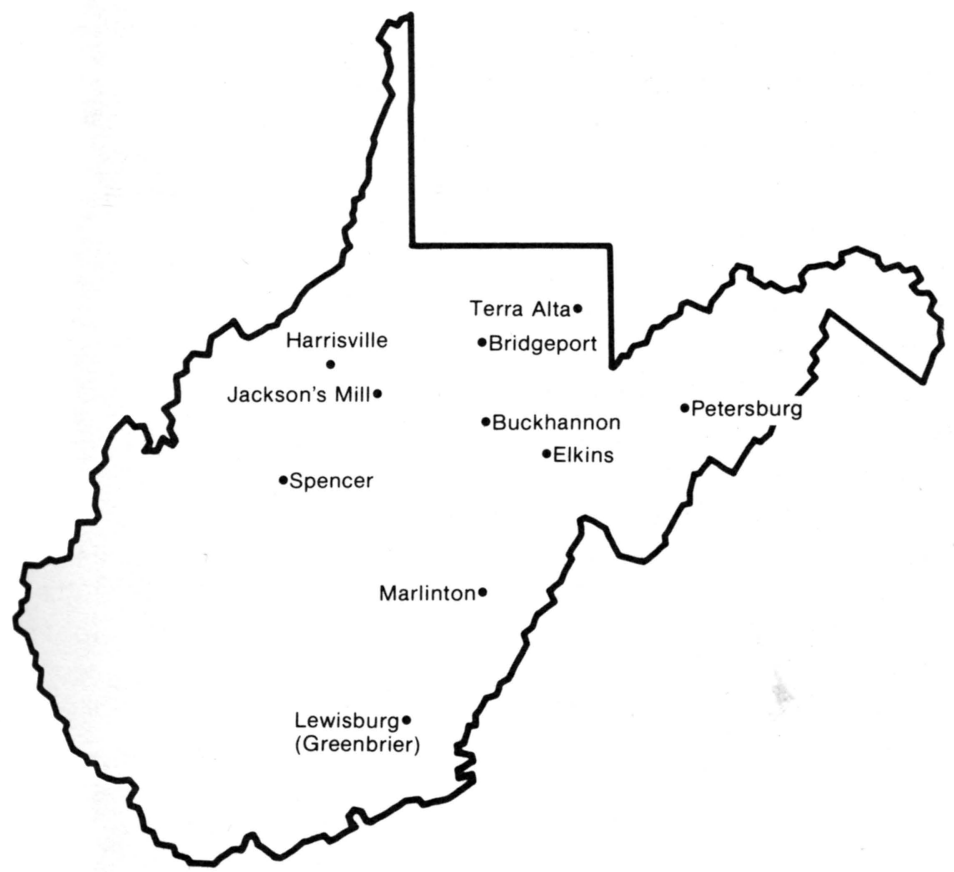

Figure 1 Location of the Ten Feeder Calf Auction Places in this Study.

Table 1

Number of Sales, Average Number of Calves per Sale and Total Number of Calves Sold Through Each Place for Years 1976 and 1977

\begin{tabular}{lcccc}
\hline \hline Sale Place & $\begin{array}{c}\text { Number of } \\
\text { Sales }^{\mathrm{a}}\end{array}$ & $\begin{array}{c}\text { Average Number Total Calves } \\
\text { of Calves/Sale }\end{array}$ & $\begin{array}{c}\text { Pold } \\
\text { Sercentage } \\
\text { of Total }^{\text {Soln }}\end{array}$ \\
\hline Petersburg & 4 & 646 & $2,586^{\mathrm{b}}$ & 7.3 \\
Greenbrier & 2 & 2,711 & 5,423 & 15.3 \\
Elkins & 4 & 1,203 & 4,812 & 13.6 \\
Jackson's Mill & 5 & 1,101 & $5,504^{\mathrm{b}}$ & 15.6 \\
Harrisville & 2 & 1,446 & 2,892 & 8.2 \\
Marlinton & 6 & 976 & $5,856^{\mathrm{b}}$ & 16.6 \\
Bridgeport & 4 & 945 & $3,742^{\mathrm{b}}$ & 10.6 \\
Buckhannon & 3 & 701 & $2,099^{\mathrm{b}}$ & 6.0 \\
Terra Alta & 3 & 412 & $1,238^{\mathrm{b}}$ & 3.5 \\
Spencer & 2 & 579 & $1,159^{\mathrm{b}}$ & 3.3 \\
\hline
\end{tabular}

"Only sales included in the analysis

"Some of the calves were not included in the analysis because all of the required data and information were not available. 
system of "fancy," "choice," "good," "standard," and "short," was used on some calves. However, these were eliminated from the statistical analysis.

There were over 80 different combinations of purebred and crossbred calves sold in the sales. Since some of these purebred and crossbred calves were so few, it was decided not to study them individually. Instead they were grouped and studied as a single breed. In so doing, the following groups were formed:

1. Purebred Angus

2. Purebred Hereford

3. Purebred Shorthorn

4. Purebred Charolais

5. Angus crosses (except BWF)

6. Hereford crosses (except BWF)

7. Angus and Charolais crosses

8. BWF (Hereford $\times$ Angus or Black and White Face)

9. Other purebreds-All purebreds other than the ones listed above. Individually the calves of these breeds were too few to be studied alone.

10. Other crosses-All crosses other than Angus crosses, Hereford crosses, and Black and White Face

Appendix C, Table 1 gives the number of observations and total numbers of calves used in the analysis in respect to each breed group.

\section{PRICE ANALYSIS}

The average price of calves in the auction sales under study ranged from a low of $\$ 12.00$ to a high of $\$ 232.50$ per hundredweight. This in itself indicates that prices of feeder calves at West Virginia auction markets are quite variable and are influenced by many factors.

In order to more effectively study price behavior under various conditions, multiple regression techniques were employed. Some of the variables introduced in a multiple regression equation take values over some continuous range and others have two or more distinct levels. An example of a continuous variable in this analysis was the average weight. But other variables such as sale place, grade, etc. were not treated as continuous variables. They were assigned levels in order to take account of the fact that the various sale places, grades, etc. could have separate deterministic effects on the dependent variable (price). Variables of this kind are usually called dummy variables (Draper and Smith, 1966).

In the analysis, dummy variables included the following: sale place, grade, breed, year, and sex.

\section{Regression Model Employed}

In this regression model, as previously stated, price was treated as the dependent variable and all other factors as independent variables (price was a function of all the other variables). The regression equation was as follows: $P=a+b_{1} X_{1}+b_{2} X_{2}+b_{3} X_{3}+b_{4} X_{4}+b_{5} X_{5}+b_{6} X_{6}+b_{7} X_{7}+b_{8} X_{8}+b_{9} X_{9}+$ $b_{10} X_{10}+b_{11} x_{11}+b_{12} X_{12}+b_{13} x_{13}+b_{14} X_{14}+e$

where the variables 


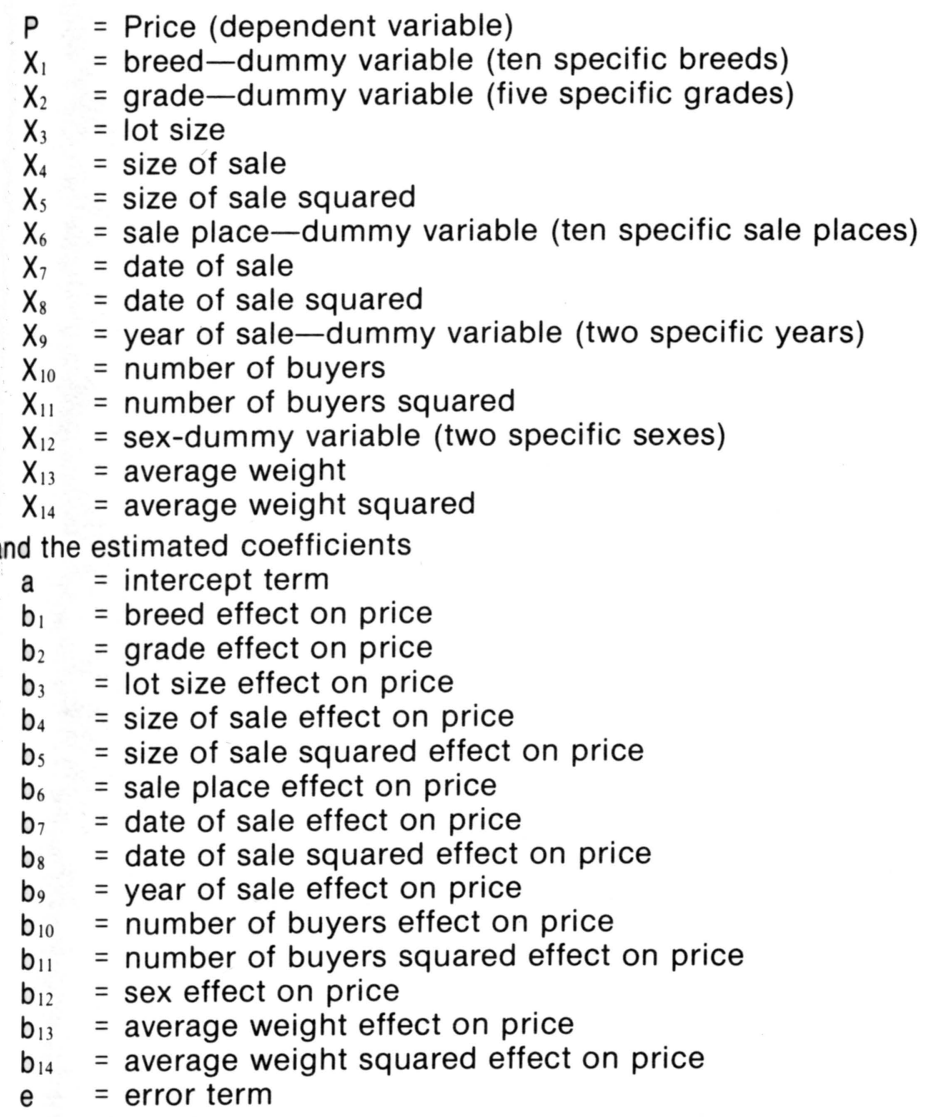

A specific representation of the dummy variable technique was used in order to more effectively interpret the results. The representation used allowed a contrast between a particular level of a dummy variable and the average of all levels of that variable.

For example, consider the case of the dummy variable breed. If the coefficient for Angus is 1.15 and the dependent variable is price per hundredweight, the price of Angus feeder calves is $\$ 1.15$ greater than the average of all breeds, assuming other variables in the equation (grade, weight, etc.) are held constant.

Another more commonly used representation contrasts a particular level of a dummy variable to the last level of that variable. However, the former representation is more valuable for this analysis.

A complete explanation of the derivations and interpretations of these techniques can be found in Kuehn and Harner (1978).

\section{The Regression Results}

The results of analysis are presented in Tables 2, 3, and 4. Table 2 shows that the f-value was 228.19 and significant at the one percent level. The coefficient of determination $\left(R^{2}\right)$, which expresses the percentage of total variability in 
price explained by all the independent variables in the regression equation, was 73.27. Table 3 gives the number of observations for each specific variable, the corresponding b-values, and the significance level. This table is used in the discussion of the effect of the independent variables on the dependent variable. Table 4 shows the contribution of the independent variable which is price per hundredweight. The f-value indicates the group variables included in the analysis which were statistically significant.

\section{The Effect of Sex on Price}

Sex was found to be the most important factor affecting the average price of feeder calves sold at the West Virginia special feeder calf sales. Sex was responsible for 59.26 percent out of the 73.27 percent variation in price explained by all variables included in the regression equation.

The coefficients were significant at the one percent level. Steers were found to realize $\$ 4.73$ higher per hundredweight than the steer-heifer average price, assuming all other variables in the model were held constant. The actual average price for steers was $\$ 40.22$ and for heifers was $\$ 27.86$ per hundredweight for the two-year period (Appendix C, Table 3).

The adjusted figure ( $b$ coefficient) does not coincide with the actual prices since it is adjusted for other variables in the model and it is assigned statistical relevance. The value of the regression coefficient is that it abstracts out influences on the price by holding all other variables affecting price at a constant level. Such coefficients can then be used to more accurately examine factors affecting the dependent variable.

Steers have historically returned higher prices than heifer calves because cattle feeders are interested in calves which will reach a certain weight within the shortest possible time. Steer calves have usually achieved a higher rate of gain than heifers.

\section{The Effect of Year on Price}

Seasonal or yearly variations in supply and demand and consequently prices of farm commodities do exist. Two years of data were hypothesized to have an influence on the price of feeder calves at the auction markets when other factors were kept constant.

Results of the analysis indicated the effect of "year" was responsible for 15.5 percent out of the total variation in price explained by all factors included in the model (Table 4).

\section{Table 2}

Analysis of Variance

\begin{tabular}{lrrrrrr}
\hline \hline $\begin{array}{l}\text { Source of } \\
\text { Variation }\end{array}$ & $\begin{array}{c}\text { Degrees of } \\
\text { Freedom }\end{array}$ & $\begin{array}{c}\text { Sum of } \\
\text { Square }\end{array}$ & $\begin{array}{c}\text { Mean } \\
\text { Square }\end{array}$ & F-Value & Prob F & R-Square \\
\hline Regression & 34 & 107076.10 & 3149.30 & 228.19 & 0.0001 & 0.7327 \\
Error & 2831 & 39070.62 & 13.80 & & & \\
Corrected Total & 2865 & 146146.72 & & & & \\
\hline
\end{tabular}

Standard Deviation 3.7150

Overall Mean Price $\$ 32.36$ 


\section{Table 3}

Variables, Number of Observations, Regression Coefficients, and Their Significance (Prob $>$ T) ${ }^{a}$

\begin{tabular}{lccc}
\hline Group Variable & Specific Variable & b Value & Prob $>$ T \\
\hline Breed & Charolais & 0.8626 & 0.0370 \\
& Angus Cross & 1.4999 & 0.0004 \\
Grade & Other Purebred & -1.0373 & 0.0208 \\
& 1 & 3.7500 & 0.0001 \\
& 2 & 2.8449 & 0.0001 \\
& 3 & -0.7204 & 0.0001 \\
Year & 4 & -0.5049 & 0.0149 \\
Sex & 5 & -5.3696 & $\mathrm{~b}$ \\
Sale Place & 1976 & -2.5089 & 0.0001 \\
& Heifer & -4.7280 & 0.0001 \\
& 201 & -1.9901 & 0.0001 \\
& 202 & 8.5193 & 0.0001 \\
& 203 & 2.1070 & 0.0001 \\
& 204 & 1.1898 & 0.0004 \\
& 205 & 1.3054 & 0.0001 \\
& 206 & -2.0511 & 0.0001 \\
Average Weight & 207 & -0.7856 & 0.0003 \\
Sale Size & 208 & -1.9266 & 0.0001 \\
Number of Buyer of Buyers Squared & 209 & -4.5318 & 0.0001 \\
\hline
\end{tabular}

"Only variables which were significant at the .05 level were presented in this table.

"The $b$ coefficients for these variables were not printed out by SAS, since they were the last of the levels of a given dummy variable to be entered. They were derived by summing all other b coefficients of the particular dummy group variable and multiplying by -1 . Their levels of significance were not determined since in each case the dummy variable as a whole was found to be statistically significant at the .05 level.

Analysis of the specific years used in the study indicated that the effects of the two years on the price were both significant at the one percent level. These results further showed that assuming all other variables in the regression equation were held constant, the 1977 average price was higher than the average of the two years by $\$ 2.64$ per hundredweight.

The actual average price of calves in 1977 was $\$ 8.61$ per hundredweight higher than that of 1976 (Appendix C, Table 2).

The analysis of grade and years (Appendix D, Table 7) showed that all the grades in 1977 returned, on the average, relatively higher prices per hundredweight than the corresponding grades in 1976. 
Table 4

Partial Regression Coefficients-Contribution of Variables to the Sum of Squares

\begin{tabular}{lrrrrr}
\hline Source & \multicolumn{3}{c}{ Sequential } & & Percent \\
\hline Breed & D.F. & \multicolumn{1}{c}{ SS } & F Value Prob $>$ F Contribution \\
Grade & 10 & 793.38 & 5.75 & 0.0001 & 0.74 \\
Year & 4 & 13761.66 & 249.29 & 0.0001 & 12.85 \\
Sex & 1 & 16596.43 & 1202.55 & 0.0001 & 15.50 \\
Sale Place & 1 & 63454.65 & 4597.83 & 0.0001 & 59.26 \\
Avg. Weight & 9 & 2804.09 & 22.58 & 0.0001 & 2.62 \\
Avg. Weight Squared & 1 & 501.06 & 36.31 & 0.0001 & \\
Sale Size & 1 & 1382.58 & 100.18 & 0.0001 & 0.12 \\
Sale Size Squared & 1 & 1939.83 & 140.56 & 0.0001 & 1.81 \\
Number of Buyers & 1 & 8.35 & 0.61 & 0.4367 & 0.01 \\
Number of Buyers Squared & 1 & 5309.26 & 384.70 & 0.0001 & \\
Date & 1 & 376.83 & 27.30 & 0.0001 & 5.31 \\
Date Squared & 1 & 93.83 & 6.80 & 0.0092 & 0.09 \\
Lot Size & 1 & 31.54 & 2.29 & 0.1307 & 0.03 \\
\hline
\end{tabular}

\section{The Effect of Grade on Price}

Grade had the third highest influence on price of all variables included in the model. It was responsible for 12.85 percent of the variation explained by all factors included in the equation and was significant at the one percent level.

As expected, grades "one" and "two" proved superior to grades "three," "four," and "five" in terms of price performance. Grades "one" and "two" realized prices of $\$ 3.75$ and $\$ 2.84$ greater per hundredweight than the average of all grades, assuming other variables were held constant.

The higher prices paid for top grades indicated that buyers recognized the grading system in their bidding. Live animal prices are a reflection of retail values of meat and meat products and their economic importance. Such prices should give incentive for producers to raise better grade calves.

\section{The Effect of the Number of Buyers on Price}

Numbers of buyers at the sales included in the analysis ranged from 14 to 39 (Table 6, Appendix C). The effect of the number of buyers on the price explained 5.31 percent out of the 73.27 percent explained by all variables. The "number of buyers" and "number of buyers squared" variables were significant at the one percent level.

Four variables (average weight, sale size, number of buyers, and date) were entered into the model in the quadratic form. This was accomplished by adding the variable into the equation a second time as a squared term in order to test the hypothesis that the relationship between one of these variables and price was curvilinear. In the case of "number of buyers," this was true.

Price was found to decrease as the number of buyers increased up to 36 . Thereafter, price began to increase. This statistical result seemed to contradict economic theory, but there is a possible explanation for this seemingly contradicting phenomenon. 
The sale sheet used to collect the data for this study (Appendix A) merely listed the names and addresses of those people buying a lot of animals. The total number of different names listed on the sale sheet was used as the "number of buyers" variable. However, buyers at auction sales usually consist of local and out-of-town farmers and order buyers who were not differentiated from each other on the sale sheets.

Order buyers purchase truckload lots of animals for large feedlot operations. Since, as agents for these feedlots they must fill relatively large orders, they might be willing to pay higher prices than local farmers.

There is usually a large number of farmers present and relatively few order buyers at a particular sale. If the number of order buyers present was very low they might have first purchased all the animals they needed at somewhat higher prices than average. After their orders were filled, the more numerous local farmers could have purchased the remaining larger number of animals at lower prices. On the other hand, if more order buyers were present, they might have purchased the majority of the animals for sale, precluding the local farmers from bidding lower prices. This could have resulted in the statistical significance of lower prices with a larger number of buyers and vice versa.

Since this explanation appears logical but is without documentation, the present study will be continued and expanded in the future to consider the nature of different buyers and their effects on price at West Virginia auctions.

\section{The Effect of Sale Place on Price}

Sale place or location explained 2.62 percent out of the 73.27 percent of the variation in price explained by all variables in the equation. Ten specific sale places were included for study. Their effects on price were all statistically significant at the one percent level.

The range in their effects on price was from $\$ 8.52$ more than the average of all locations to $\$ 4.53$ less than this average.

The fact that these coefficients were adjusted for all other variables in the equation means that the particular location, in itself, was responsible for realizing higher or lower prices than other locations. Prices were higher at the larger sale places but at any given sale place the larger the number of animals offered for sale, the lower the price.

\section{The Effect of Size of Sale on Price}

Size of sale is the total number of calves offered for sale on a scheduled day. The size of sale effect on price was 1.81 percent out of the 73.27 percent explained by all variables and was significant at the one percent level.

The $b$ coefficient of -0.0034 indicated a very small negative effect on price assuming all other variables were held constant. More specifically, as the size of sale increased, the average price per hundredweight decreased slightly. The sale size squared variable was not statistically significant.

\section{The Effect of Breed on Price}

The overall effect of breed on the price of feeder calves was statistically significant at the one percent level. However, this variable was responsible for only 0.74 percent out of the 73.27 percent variation in price explained by all the variables included in the equation (Table 4).

The results of the estimates concerning the specific breed variables are presented in Table 3 . Ten specific breeds were included in the analysis. 
However, only the three shown in Table 3 had statistically significant regression coefficients.

Charolais realized $\$ .86$ higher than the average of all breeds, Angus crosses (except BWF) realized $\$ 1.50$ more, and other purebreds received $\$ 1.04$ less than the average of all breeds, assuming other variables were held constant. The other breeds in the equation did not have statistically significant effects on the price.

Analyzing the breeds by numbers indicated that Hereford and Angus calves dominated the sales included in the study. Calves of these two breeds accounted for almost 60 percent of the total calves included in the analysis (Appendix C, Table 1). The fact that these breeds dominated the total number was probably the reason they did not have statistically significant effects on price. Their effects were not significantly greater or less than the average of all breeds as was the case for Charolais, Angus crosses, and for other purebreds.

\section{The Effect of Average Weight on Price}

Although the effect of average weight on price was statistically significant, it was only responsible for 0.12 percent out of the 73.27 percent variation in price explained by all the variables included in the regression equation. Both average weight and average weight squared were used in the regression equation as variables. They were both significant at the one percent level (Table 3 ). The results indicated that there was an increase in the average price as the average weight increased up to 508 pounds; thereafter, the price started declining.

Most of the feeder calves sold in these sales fell within an average weight range of $400-470$ pounds. The analysis of average weight by breed (Appendix $\mathrm{C}$, Table 1) indicated that Hereford crosses were the heaviest ( 464 pounds) and Black-White Face the lightest (439 pounds).

An analysis of sex and average weight revealed that on the average steers were heavier than heifers by 27 pounds (Appendix C, Table 3).

The grade and average weight analysis revealed some positive correlation between grade and average weight. Calves which graded "fancy," "choice," and "one," grades which are supposed to be superior to the rest, averaged relatively higher in weight than the rest of the calves in the lower grades (Appendix C, Table 5).

A possible reason that calves of above average weight, 508 pounds and above, returned a lower average price than the lighter ones might be that cattle feeders do not expect as high a rate of daily gain as they would expect from lighter calves and are therefore not willing to pay as high a price.

\section{The Effects of Date of Sale and Lot Size on Price}

Date of Sale. Most agricultural commodities including feeder calves are subject to seasonal variations in supply and demand. Such variations result in price changes. The dates on which the sales were held were expected to have an effect on the price of feeder calves.

However, the effect of date of sale on feeder calf prices was not found to be statistically significant. All sales included in this study were held between the middle of September and the end of October each year. Although the actual data (Appendix C, Table 6), show possible trends in price, the short time period during each year precluded any statistically significant conclusions. 
Lot Size. Feeder calves at auction markets are sold in lots of various numbers of animals. For purposes of analysis, each lot size was treated as a single animal. Calves in each lot size were assumed to be of the same sex, breed, and grade. The number of calves in each lot size ranged from a low of 1 to a high of over 80 . Because of this variation in the number of calves in each lot, that lot size was expected to have an effect on the price of calves, if all other variables included in the regression equation were held constant. However, the results indicated that effect on price due to lot size was not statistically significant. There was a correlation between lot size and size of sale. Since the size of sale effect on price was statistically significant, it can be assumed that it overshadowed the lot size effect.

Another explaining factor is that lot sizes could be in the ranges desired by many buyers. In the past, lot sizes were smaller, making it difficult for order buyers to fill their trucks. Lately, lot sizes have been larger and in sizes which allow more efficient distribution. If this is the case, the effect of lot size on price would not be as great presently as it has been in the past.

\section{Literature Cited}

Draper, N. R. and H. Smith. Applied Regression Analysis. John Wiley and Sons, Inc. (New York, London, Sydney) 1966, pp. 134, 243-252.

Dunn, O. J. and Virginia A. Clark. Applied Statistics, Analysis of Variance and Regression. John Wiley and Sons (New York, London, Sydney, Toronto). 1974, pp. 252-266.

Emch, Joseph C. "West Virginia Feeder Calf Sales." West Virginia University 1969 Summary. Mimeograph. 1969.

"West Virginia Feeder Calf Marketing Programs." The Market Bull. Charleston. August 10, 1967, Vol. 51, No. 23, p. 1.

" "1967 State Feeder Calves Top Last Year's Prices." The Market Bull. Charleston. December 20, 1967. Vol. 51, No. 36, p. 1.

Golden, D. P. and John P. Kuehn. Prices and Volumes of Livestock Sold in West Virginia Auction Markets 1960-1969. West Virginia University Agr. Exp. Sta. Bull. 607. March 1972.

Kuehn, J. P. and E. James Harner. "Alternative Representations of Dummy Variables and Their Interpretations." J. of the Northeastern Agric. Economics Council. Vol. VII, No. 1, April, 1978. 
Blank Page in Original Bulletin 
Appendixes 


\section{Appendix A}

Table 1

Sale Sheet Steers

\begin{tabular}{|c|c|c|c|c|c|c|c|}
\hline Grade & Pen & No & Kind & $\begin{array}{c}\text { Average } \\
\text { Weight }\end{array}$ & $\begin{array}{c}\text { Total } \\
\text { Weight }\end{array}$ & Price & Buyer \\
\hline 1 & 1 & 9 & $\mathrm{HS}$ & 338 & 3,045 & & \\
\hline 1 & 20 & 4 & BWF S & 336 & 1,345 & & \\
\hline 1 & 20 & 1 & Ch S & 355 & 355 & & \\
\hline 1 & 22 & 46 & $\mathrm{HS}$ & 405 & 18,650 & & \\
\hline 1 & 9 & 22 & B S & 406 & 8,930 & & \\
\hline 1 & 27 & 77 & $\mathrm{HS}$ & 486 & 37,395 & & \\
\hline 1 & 15 & 17 & BWF S & 415 & 7,060 & & \\
\hline 1 & 0 & 21 & Ch S & 400 & 8,410 & & \\
\hline 1 & 8 & 19 & $B S$ & 488 & 9,270 & & \\
\hline 1 & 77 & 36 & Ch S & 496 & 17,850 & & \\
\hline 1 & 2 & 28 & BWF S & 488 & 13,655 & & \\
\hline 1 & 6 & 4 & Ch S & 424 & 1,695 & & \\
\hline 1 & 7 & 31 & $\mathrm{HS}$ & 596 & 18,465 & & \\
\hline 1 & 6 & 19 & Ch S & 610 & 11,585 & & \\
\hline 1 & 4 & 12 & BWF S & 627 & 7,525 & & \\
\hline 2 & 10 & 25 & $\mathrm{HS}$ & 412 & 10,300 & & \\
\hline 2 & 50 & 21 & B S & 504 & 10,575 & & \\
\hline 2 & 50 & 3 & Ch S & 485 & 1,455 & & \\
\hline 2 & 3 & 21 & B S & 401 & 8,425 & & \\
\hline 2 & 3 & 3 & Ch S & 403 & 1,210 & & \\
\hline 2 & $A$ & 16 & $\mathrm{HS}$ & 480 & 7,680 & & \\
\hline 2 & $B$ & 15 & B S & 333 & 5,000 & & \\
\hline 2 & 76 & 6 & $B S$ & 594 & 3,565 & & \\
\hline 2 & 76 & 3 & $\mathrm{HS}$ & 578 & 1,735 & & \\
\hline 2 & 19 & 3 & HS & 340 & 1,020 & & \\
\hline 3 & 73 & 2 & $\mathrm{HS}$ & 337 & 675 & & \\
\hline 3 & 73 & 3 & $B S$ & 340 & 1,020 & & \\
\hline 3 & 73 & 2 & Ch S & 328 & 655 & & \\
\hline 3 & 74 & 7 & $\mathrm{HS}$ & 395 & 2,765 & & \\
\hline 3 & 74 & 9 & B S & 401 & 3,610 & & \\
\hline 3 & 75 & 7 & $\mathrm{HS}$ & 483 & 3,380 & & \\
\hline 3 & 75 & 4 & B S & 490 & 1,960 & & \\
\hline 3 & 75 & 3 & Ch S & 488 & 1,465 & & \\
\hline 3 & 78 & 3 & Ch S & 630 & 1,890 & & \\
\hline 3 & 78 & 1 & $B S$ & 590 & 590 & & \\
\hline 4 & Scales & 9 & B S & 396 & 3,565 & & \\
\hline 4 & 33 & 10 & B S & 474 & 4,735 & & \\
\hline 4 & 33 & 5 & $\mathrm{HS}$ & 477 & 2,385 & & \\
\hline 4 & 33 & 2 & Ch S & 515 & 1,030 & & \\
\hline 4 & 45 & 5 & B S & 329 & 1,645 & & \\
\hline 4 & 45 & 1 & $\mathrm{HS}$ & 355 & 355 & & \\
\hline 4 & $\mathrm{C}$ & 7 & $\mathrm{HS}$ & 408 & 2,855 & & \\
\hline 4 & $\mathrm{C}$ & 1 & Ch S & 365 & 365 & & \\
\hline 4 & 49 & 1 & $\mathrm{HS}$ & 565 & 565 & & \\
\hline
\end{tabular}

Total Steers $=544$ 


\section{Appendix A}

\section{Table 2}

Sale Sheet Heifers

\begin{tabular}{|c|c|c|c|c|c|c|c|}
\hline Grade & Pen & No & Kind & $\begin{array}{c}\text { Average } \\
\text { Weight }\end{array}$ & $\begin{array}{c}\text { Total } \\
\text { Weight }\end{array}$ & Price & Buyer \\
\hline $\begin{array}{l}1 \\
1 \\
1 \\
1 \\
1 \\
1 \\
1 \\
1 \\
1 \\
1 \\
1 \\
1 \\
1 \\
1 \\
1 \\
1\end{array}$ & $\begin{array}{l}60 \\
59 \\
31 \\
17 \\
47 \\
47 \\
67 \\
63 \\
61 \\
64 \\
64 \\
62 \\
51 \\
65 \\
65 \\
65\end{array}$ & $\begin{array}{r}14 \\
16 \\
11 \\
4 \\
2 \\
1 \\
1 \\
35 \\
26 \\
15 \\
10 \\
4 \\
25 \\
14 \\
11 \\
2 \\
2\end{array}$ & $\begin{array}{l}\mathrm{HH} \\
\mathrm{ChH} \\
\text { BWF H } \\
\text { B H } \\
\text { Ch H } \\
\text { VWF H } \\
\mathrm{H} \mathrm{H} \\
\mathrm{Ch} \mathrm{H} \\
\text { B H } \\
\text { BWF H } \\
\mathrm{H} \mathrm{H} \\
\mathrm{H} H \\
\text { B H } \\
\text { Ch H } \\
\text { B H } \\
\text { BWF H }\end{array}$ & $\begin{array}{l}337 \\
391 \\
387 \\
348 \\
310 \\
290 \\
415 \\
489 \\
416 \\
494 \\
586 \\
489 \\
504 \\
630 \\
550 \\
555\end{array}$ & $\begin{array}{r}4,715 \\
6,250 \\
4,255 \\
1,390 \\
620 \\
290 \\
14,515 \\
12,725 \\
6,235 \\
4,940 \\
2,345 \\
12,225 \\
7,050 \\
6,930 \\
1,100 \\
1,110\end{array}$ & & \\
\hline $\begin{array}{l}2 \\
2 \\
2 \\
2 \\
2 \\
2 \\
2 \\
2 \\
2\end{array}$ & $\begin{array}{c}18 \\
56 \\
66 \\
32 \\
28 \& 29 \\
68 \\
30 \\
30 \\
44\end{array}$ & $\begin{array}{r}8 \\
35 \\
16 \\
12 \\
33 \\
27 \\
7 \\
5 \\
3\end{array}$ & $\begin{array}{l}\mathrm{HH} \\
\mathrm{HH} \\
\mathrm{HH} \\
\mathrm{BH} \\
\mathrm{BH} \\
\mathrm{BH} \\
\mathrm{BWFH} \\
\mathrm{ChH} \\
\mathrm{ChH}\end{array}$ & $\begin{array}{l}338 \\
405 \\
496 \\
325 \\
405 \\
486 \\
648 \\
524 \\
407\end{array}$ & $\begin{array}{r}2,700 \\
14,180 \\
7,935 \\
3,895 \\
13,375 \\
13,115 \\
4,535 \\
2,620 \\
1,220\end{array}$ & & \\
\hline $\begin{array}{l}3 \\
3 \\
3 \\
3 \\
3 \\
3 \\
3 \\
3 \\
3 \\
3\end{array}$ & $\begin{array}{l}54 \\
25 \\
25 \\
69 \\
69 \\
55 \\
55 \\
21 \\
21 \\
23\end{array}$ & $\begin{array}{r}10 \\
11 \\
4 \\
1 \\
3 \\
7 \\
1 \\
5 \\
1 \\
5\end{array}$ & $\begin{array}{l}\mathrm{HH} \\
\mathrm{BWFH} \\
\mathrm{Ch} \mathrm{H} \\
\mathrm{HH} \\
\mathrm{ChH} \\
\mathrm{H} \mathrm{H} \\
\mathrm{Ch} \mathrm{H} \\
\mathrm{B} \mathrm{H} \\
\mathrm{Ch} \mathrm{H} \\
\mathrm{BH}\end{array}$ & $\begin{array}{l}405 \\
407 \\
402 \\
555 \\
612 \\
342 \\
320 \\
481 \\
470 \\
336\end{array}$ & $\begin{array}{r}4,055 \\
4,475 \\
1,610 \\
555 \\
1,835 \\
2,395 \\
320 \\
2,405 \\
470 \\
1,680\end{array}$ & & \\
\hline $\begin{array}{l}4 \\
4 \\
4 \\
4 \\
4\end{array}$ & $\begin{array}{l}72 \\
70 \\
71 \\
71 \\
71 \\
\end{array}$ & $\begin{array}{r}16 \\
9 \\
1 \\
6 \\
3 \\
\end{array}$ & $\begin{array}{l}\mathrm{BH} \\
\mathrm{BH} \\
\mathrm{H} H \\
\mathrm{H} H \\
\mathrm{Ch} \mathrm{H}\end{array}$ & $\begin{array}{l}409 \\
327 \\
330 \\
410 \\
540\end{array}$ & $\begin{array}{r}6,540 \\
2,945 \\
330 \\
2,460 \\
1,620\end{array}$ & & \\
\hline
\end{tabular}

Total Heifers $=421$ 


\section{Appendix B}

West Virginia Feeder Calf and Cattle Grade Standards

\section{Number 1-Large Frame}

Moderately thick to thick muscling

Potential slaughter weight-

Steers $1,000 \mathrm{lbs}$. or more

Heifers 900 lbs. or more

Possible carcass grade-choice-yield 1 to 3

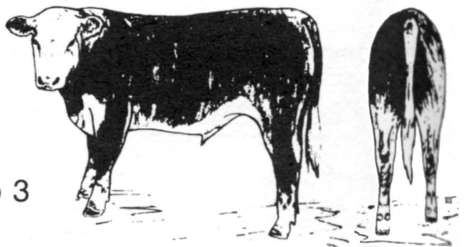

\section{Number 2-Medium Frame}

Moderately thick to thick muscling

Potential slaughter weight-

Steers under 1,000 lbs.

Heifers under $900 \mathrm{lbs}$.

Possible carcass grade-choice-yield 1 to 3

\section{Number 3-Large Frame}

Slightly thick to slightly thin muscling

Potential slaughter weight-

Steers approx. 1,000 lbs.

Heifers approx. $900 \mathrm{lbs}$.

Possible carcass grade-choice-yield 1 to 3

\section{Number 4-Small Frame}

Moderately thick to thick muscle

Potential slaughter weight-

Steers under $900 \mathrm{lbs}$.

Heifers under $800 \mathrm{lbs}$.

Very early maturing

\section{Number 5-Medium to Large Frame}

Thin muscling

Number 1

Number 2

Number 3

Number 4

Number 5

\section{MARKS}

No mark

Mark on shoulder

Mark on back

S

Mark on tail
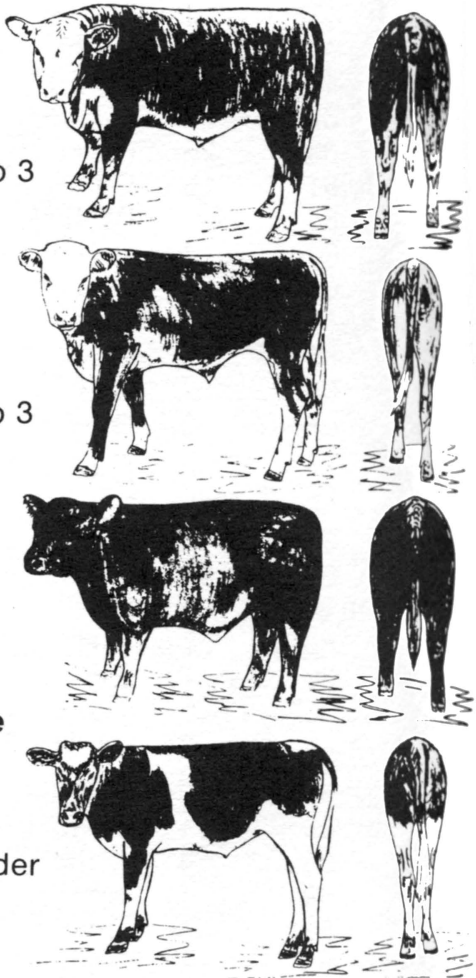


\section{Appendix C \\ Table 1}

Number of Observations, Total Number of Head,

Average Weight, and Average Price per

Hundredweight by Breed for Calves Included in

This Analysis

\begin{tabular}{|c|c|c|c|c|c|c|}
\hline Breed & $\begin{array}{c}\text { Number of } \\
\text { Observations } \\
\text { or Pens }\end{array}$ & Percent & $\begin{array}{l}\text { Number } \\
\text { of Head }\end{array}$ & Percent & $\begin{array}{c}\text { Average } \\
\text { Weight }\end{array}$ & $\begin{array}{c}\text { Average } \\
\text { Price }\end{array}$ \\
\hline Angus & 574 & 18.1 & 7,220 & 21.3 & 449 & 34.21 \\
\hline BWF & 224 & 7.1 & 1,515 & 4.5 & 439 & 32.00 \\
\hline Charolais & 339 & 10.7 & 2,427 & 7.1 & 451 & 33.86 \\
\hline Hereford & 822 & 25.9 & 12,863 & 37.9 & 442 & 34.28 \\
\hline Angus Cross & 289 & 9.1 & 3,147 & 9.3 & 456 & 33.45 \\
\hline Char & 163 & 5.1 & 1,019 & 3.0 & 444 & 31.91 \\
\hline Hereford Cross & 166 & 5.2 & 2,568 & 7.6 & 464 & 36.02 \\
\hline MBRD & 288 & 9.1 & 1,078 & 3.2 & 463 & 46.86 \\
\hline Shorthorn & 30 & 0.9 & 78 & 0.2 & 457 & 37.27 \\
\hline Other Crosses & 278 & 8.8 & 2,021 & 5.9 & 454 & 32.79 \\
\hline Total & 3,173 & 100.0 & 33,936 & 100.0 & 450 & 35.26 \\
\hline
\end{tabular}

\section{Appendix C}

Table 2

Number of Observations, Total Number of Head,

Average Weight, and Average Price per

Hundredweight by Years for Calves Included in

This Analysis

\begin{tabular}{|c|c|c|c|c|c|c|}
\hline Year & $\begin{array}{c}\text { Number of } \\
\text { Observations } \\
\text { or Pens }\end{array}$ & Percent & $\begin{array}{l}\text { Number } \\
\text { of Head }\end{array}$ & Percent & $\begin{array}{l}\text { Average } \\
\text { Weight }\end{array}$ & $\begin{array}{c}\text { Average } \\
\text { Price }\end{array}$ \\
\hline 1976 & 1,379 & 43.4 & 15,994 & 47.1 & 448 & 30.12 \\
\hline 1977 & 1,796 & 56.6 & 17,993 & 52.9 & 452 & 38.73 \\
\hline Total & 3,175 & 100.0 & 33,987 & 100.0 & 450 & 34.42 \\
\hline
\end{tabular}




\section{Appendix C}

Table 3

Number of Observations, Total Number of Head, Average Weight, and Average Price per

Hundredweight by Sex for Calves Included in This Analysis

\begin{tabular}{|c|c|c|c|c|c|c|}
\hline Sex & $\begin{array}{l}\text { Number of } \\
\text { Observations } \\
\text { or Pens }\end{array}$ & Percent & $\begin{array}{l}\text { Number } \\
\text { of Head }\end{array}$ & Percent & $\begin{array}{l}\text { Average } \\
\text { Weight }\end{array}$ & $\begin{array}{c}\text { Average } \\
\text { Price }\end{array}$ \\
\hline & 1,832 & 57.7 & 18,727 & 55.1 & 461 & 40.22 \\
\hline Heifer & 1,343 & 42.3 & 15,260 & 44.9 & 434 & 27.86 \\
\hline Total & 3,175 & 100.0 & 33,987 & 100.0 & 448 & 34.04 \\
\hline
\end{tabular}

\section{Appendix C}

Table 4

Number of Observations, Total Number of Head, Average Weight, and Average Price per

Hundredweight by Sale Place for Calves Included in This Analysis

\begin{tabular}{|c|c|c|c|c|c|c|}
\hline $\begin{array}{l}\text { Sale } \\
\text { Place } \\
\text { Code }\end{array}$ & $\begin{array}{c}\text { Number of } \\
\text { Observations } \\
\text { or Pens }\end{array}$ & Percent & $\begin{array}{l}\text { Number } \\
\text { of Head }\end{array}$ & Percent & $\begin{array}{c}\text { Average } \\
\text { Weight }\end{array}$ & $\begin{array}{c}\text { Average } \\
\text { Price }\end{array}$ \\
\hline 201 & 335 & 10.6 & 2,436 & 7.2 & 449 & 33.17 \\
\hline 202 & 176 & 5.5 & 5,423 & 15.9 & 464 & 34.43 \\
\hline 203 & 389 & 12.2 & 4,812 & 14.1 & 450 & 32.46 \\
\hline 204 & 609 & 19.2 & 5,501 & 16.2 & 458 & 45.98 \\
\hline 205 & 262 & 8.3 & 2,892 & 8.5 & 438 & 32.32 \\
\hline 206 & 528 & 16.6 & 5,731 & 16.9 & 467 & 32.85 \\
\hline 207 & 308 & 9.7 & 3,386 & 10.0 & 431 & 31.44 \\
\hline 208 & 257 & 8.1 & 2,094 & 6.2 & 439 & 31.47 \\
\hline 209 & 190 & 6.0 & 1,097 & 3.2 & 433 & 31.16 \\
\hline 210 & 121 & 3.8 & 615 & 1.8 & 434 & 31.35 \\
\hline Total & 3,175 & 100.0 & 33,987 & 100.0 & 450 & 34.99 \\
\hline
\end{tabular}




\section{Appendix C}

Table 5

Number of Observations, Total Number of Head, Average Weight, and Average Price per

Hundredweight by Grade for Calves Included in This Analysis

\begin{tabular}{|c|c|c|c|c|c|c|}
\hline Grade & $\begin{array}{c}\text { Number of } \\
\text { Observations } \\
\text { or Pens }\end{array}$ & Percent & $\begin{array}{l}\text { Number } \\
\text { of Head }\end{array}$ & Percent & $\begin{array}{c}\text { Average } \\
\text { Weight }\end{array}$ & $\begin{array}{c}\text { Average } \\
\text { Price }\end{array}$ \\
\hline 1 & 1,165 & 36.7 & 15,270 & 44.90 & 468 & 34.02 \\
\hline 2 & 786 & 24.7 & 10,613 & 31.20 & 437 & 33.32 \\
\hline 3 & 564 & 17.8 & 4,849 & 14.30 & 432 & 29.50 \\
\hline 4 & 283 & 8.9 & 2,321 & 6.80 & 426 & 30.45 \\
\hline 5 & 69 & 2.2 & 256 & 0.70 & 424 & 24.75 \\
\hline Fancy & 162 & 5.1 & 162 & 0.50 & 493 & 72.55 \\
\hline Choice & 93 & 2.9 & 325 & 1.00 & 469 & 46.65 \\
\hline Good & 31 & 1.0 & 123 & 0.40 & 448 & 44.31 \\
\hline Standard & 6 & 0.2 & 13 & 0.04 & 384 & 35.83 \\
\hline Short & 16 & 0.5 & 55 & 0.16 & 422 & 39.94 \\
\hline Total & 3,175 & 100.0 & 33,987 & 100.00 & 450 & 34.99 \\
\hline
\end{tabular}




\section{Appendix C}

Table 6

Sale Places, Dates Sales Took Place, Size of Sale, and Number of Buyers 1976 and 1977

\begin{tabular}{|c|c|c|c|}
\hline Sale Place Code & $\begin{array}{c}\text { Date and Year } \\
\text { of Sale }\end{array}$ & Size of Sale & $\begin{array}{c}\text { Number of } \\
\text { Buyers }\end{array}$ \\
\hline 201 & $\begin{array}{c}10-21-76 \\
9-30-76 \\
10-20-77 \\
9-30-77\end{array}$ & $\begin{array}{l}527 \\
516 \\
893 \\
650\end{array}$ & $\begin{array}{l}27 \\
25 \\
19 \\
25\end{array}$ \\
\hline 202 & $\begin{array}{c}10-6-76 \\
10-12-77\end{array}$ & $\begin{array}{l}3,226 \\
2,197\end{array}$ & $\begin{array}{l}27 \\
30\end{array}$ \\
\hline 203 & $\begin{array}{l}10-12-76 \\
10-19-76 \\
10-18-77 \\
10-11-77\end{array}$ & $\begin{array}{l}1,183 \\
1,116 \\
1,185 \\
1,324\end{array}$ & $\begin{array}{l}24 \\
36 \\
29 \\
30\end{array}$ \\
\hline 204 & $\begin{array}{l}10-7-76 \\
9-29-76 \\
9-29-77 \\
10-6-77 \\
9-15-77\end{array}$ & $\begin{array}{r}1,628 \\
953 \\
1,128 \\
1,146 \\
649\end{array}$ & $\begin{array}{l}34 \\
27 \\
20 \\
21 \\
39\end{array}$ \\
\hline 205 & $\begin{array}{l}10-22-76 \\
10-21-77\end{array}$ & $\begin{array}{l}1,365 \\
1,527\end{array}$ & $\begin{array}{l}32 \\
30\end{array}$ \\
\hline 206 & $\begin{array}{c}10-29-76 \\
10-15-76 \\
10-18-76 \\
10-14-77 \\
10-7-77 \\
10-28-77\end{array}$ & $\begin{array}{r}748 \\
1,131 \\
947 \\
1,125 \\
900 \\
1,005\end{array}$ & $\begin{array}{l}24 \\
15 \\
16 \\
17 \\
14 \\
31\end{array}$ \\
\hline 207 & $\begin{array}{c}10-22-76 \\
10-8-76 \\
10-21-77 \\
10-7-77\end{array}$ & $\begin{array}{r}822 \\
619 \\
1,557 \\
744\end{array}$ & $\begin{array}{l}19 \\
30 \\
35 \\
23\end{array}$ \\
\hline 208 & $\begin{array}{c}10-1-76 \\
10-16-76 \\
10-1-77\end{array}$ & $\begin{array}{l}715 \\
419 \\
965\end{array}$ & $\begin{array}{l}21 \\
29 \\
17\end{array}$ \\
\hline 209 & $\begin{array}{c}10-20-76 \\
10-19-77 \\
10-5-77\end{array}$ & $\begin{array}{l}397 \\
606 \\
235\end{array}$ & $\begin{array}{l}24 \\
22 \\
22\end{array}$ \\
\hline 210 & $\begin{array}{l}10-18-76 \\
10-17-77\end{array}$ & $\begin{array}{l}499 \\
660\end{array}$ & $\begin{array}{l}22 \\
36\end{array}$ \\
\hline
\end{tabular}




\section{Appendix C \\ Table 7}

Estimation of Average Sale Date for Each Year and Overall Average for the Two Years for the Sales Included in This Analysis

\begin{tabular}{|c|c|c|c|}
\hline \multirow[b]{2}{*}{ Sale Place Code } & \multirow{2}{*}{$\begin{array}{c}\text { Sale } \\
\text { Number }\end{array}$} & \multicolumn{2}{|c|}{$\begin{array}{l}\text { Day of the Year and } \\
\text { Year Sale Was Held }\end{array}$} \\
\hline & & 1976 & 1977 \\
\hline 201 & $\begin{array}{l}1 \\
2\end{array}$ & $\begin{array}{l}295 \\
274\end{array}$ & $\begin{array}{l}293 \\
273\end{array}$ \\
\hline 202 & 1 & 280 & 285 \\
\hline 203 & $\begin{array}{l}1 \\
2\end{array}$ & $\begin{array}{l}286 \\
293\end{array}$ & $\begin{array}{l}291 \\
284\end{array}$ \\
\hline 204 & $\begin{array}{l}1 \\
2 \\
3\end{array}$ & $\begin{array}{c}281 \\
273 \\
-\end{array}$ & $\begin{array}{l}272 \\
279 \\
258\end{array}$ \\
\hline 205 & 1 & 296 & 294 \\
\hline 206 & $\begin{array}{l}1 \\
2 \\
3\end{array}$ & $\begin{array}{l}303 \\
289 \\
282\end{array}$ & $\begin{array}{l}287 \\
280 \\
301\end{array}$ \\
\hline 207 & $\begin{array}{l}1 \\
2\end{array}$ & $\begin{array}{l}296 \\
282\end{array}$ & $\begin{array}{l}294 \\
280\end{array}$ \\
\hline 208 & $\begin{array}{l}1 \\
2\end{array}$ & $\begin{array}{l}275 \\
290\end{array}$ & $\begin{array}{c}274 \\
-\end{array}$ \\
\hline 209 & $\begin{array}{l}1 \\
2\end{array}$ & $\begin{array}{c}294 \\
-\end{array}$ & $\begin{array}{l}292 \\
278\end{array}$ \\
\hline 210 & 1 & 292 & 290 \\
\hline Average & & 287 & 283 \\
\hline
\end{tabular}

\section{Average Sale Date}

1976-287 or October 13

1977-283 or October 10

Overall average sale date for the two years $=284$ th day of the year, or October 11 . 


\section{Appendix D}

\section{Table 1}

Means for Sale Place by Grade for Calves Included in This Analysis

\begin{tabular}{|c|c|c|c|c|c|c|}
\hline $\begin{array}{c}\text { Sale } \\
\text { Place Code }\end{array}$ & Grade & $\begin{array}{c}\text { Number of } \\
\text { Observations }\end{array}$ & $\begin{array}{c}\text { Number } \\
\text { Head }\end{array}$ & $\begin{array}{l}\% \text { in } \\
\text { Grade }\end{array}$ & $\begin{array}{l}\text { Av. } \\
\text { Wt. }\end{array}$ & $\begin{array}{l}\text { Av. } \\
\text { Price }\end{array}$ \\
\hline 201 & $\begin{array}{l}1 \\
2 \\
3 \\
4 \\
5\end{array}$ & $\begin{array}{r}150 \\
90 \\
48 \\
39 \\
8\end{array}$ & $\begin{array}{r}866 \\
1,035 \\
297 \\
230 \\
8\end{array}$ & $\begin{array}{r}35.6 \\
42.5 \\
12.2 \\
9.4 \\
.3\end{array}$ & $\begin{array}{l}467 \\
425 \\
437 \\
448 \\
503\end{array}$ & $\begin{array}{l}33.22 \\
34.51 \\
32.22 \\
32.40 \\
26.31\end{array}$ \\
\hline 202 & $\begin{array}{l}1 \\
2 \\
3 \\
4 \\
5\end{array}$ & $\begin{array}{r}83 \\
49 \\
33 \\
7 \\
4\end{array}$ & $\begin{array}{r}2,850 \\
1,303 \\
1,026 \\
166 \\
78\end{array}$ & $\begin{array}{r}52.6 \\
24.0 \\
18.9 \\
3.1 \\
1.4\end{array}$ & $\begin{array}{l}483 \\
451 \\
452 \\
400 \\
431\end{array}$ & $\begin{array}{l}37.61 \\
33.33 \\
30.35 \\
29.86 \\
23.44\end{array}$ \\
\hline 203 & $\begin{array}{l}1 \\
2 \\
3 \\
4 \\
5 \\
\text { FA }\end{array}$ & $\begin{array}{r}138 \\
102 \\
78 \\
49 \\
14 \\
8\end{array}$ & $\begin{array}{r}2,021 \\
1,573 \\
700 \\
463 \\
47 \\
8\end{array}$ & $\begin{array}{r}42.0 \\
32.7 \\
14.5 \\
9.6 \\
1.0 \\
0.2\end{array}$ & $\begin{array}{l}476 \\
440 \\
432 \\
421 \\
428 \\
548\end{array}$ & $\begin{array}{l}34.27 \\
33.36 \\
29.18 \\
30.62 \\
25.30 \\
45.75\end{array}$ \\
\hline 204 & $\begin{array}{l}1 \\
2 \\
3 \\
4 \\
5 \\
\text { Fancy } \\
\text { Choice } \\
\text { Good } \\
\text { Standard } \\
\text { Short }\end{array}$ & $\begin{array}{r}129 \\
90 \\
51 \\
37 \\
19 \\
137 \\
93 \\
31 \\
6 \\
\mathbf{1 6}\end{array}$ & $\begin{array}{r}2,407 \\
1,397 \\
559 \\
434 \\
51 \\
137 \\
325 \\
123 \\
13 \\
55\end{array}$ & $\begin{array}{r}43.8 \\
25.4 \\
10.2 \\
7.9 \\
0.9 \\
2.5 \\
5.9 \\
2.2 \\
0.2 \\
1.0\end{array}$ & $\begin{array}{l}459 \\
440 \\
444 \\
422 \\
438 \\
490 \\
469 \\
448 \\
384 \\
422\end{array}$ & $\begin{array}{l}35.92 \\
35.07 \\
30.82 \\
29.67 \\
24.35 \\
76.76 \\
46.65 \\
44.31 \\
35.83 \\
30.94\end{array}$ \\
\hline
\end{tabular}


205

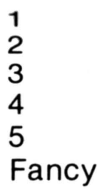

206

2

3

207

$$
1
$$$$
2
$$

3

$$
\begin{aligned}
& 4 \\
& 5
\end{aligned}
$$

208

2
3
4

209

210

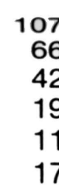

107
66
42
19
11
17

197

156

108

67

122

78

72

23

13

99

64

57

37

93

52

40

5

47

39

1,215
871
556
189
44
17
2,073
2,344
815
499
1,766
958
469
165
28
1,162
590
190
152
640
334
100
23
270
208
137

42.0
30.1
19.2

6.5

1.5

0.6

36.2

40.9

14.2

8.7

52.2

28.3

13.8

4.9

0.8

55.5

28.2

9.1

7.2

58.3

30.4

9.1

2.1

43.9

33.8

22.3
451

428

428

409

372

486

494

463

438

444

456

423

414

397

391

455

437

425

420

449

403

432

420

456

417

422
33.88

28.02

26.80

21.09

51.29

34.33

34.12

29.72

30.58

32.71

32.97

28.85

30.03

27.21

32.86

32.32

28.57

30.71

31.83

31.94

28.44

32.45

33.42

31.11

28.83 


\section{Appendix D}

Table 2

Means for Sex by Grade for Calves Included in the Analysis

\begin{tabular}{lrcrrrr}
\hline \hline Sex & Grade & $\begin{array}{c}\text { Number of } \\
\text { Observations }\end{array}$ & $\begin{array}{c}\text { Number } \\
\text { Head }\end{array}$ & $\begin{array}{c}\text { \% in } \\
\text { Grade }\end{array}$ & $\begin{array}{c}\text { Av. } \\
\text { Weight }\end{array}$ & $\begin{array}{c}\text { Av. } \\
\text { Price }\end{array}$ \\
\hline Steer & 1 & 642 & 8,428 & 45.00 & 479 & 38.57 \\
& 2 & 439 & 5,922 & 31.60 & 449 & 37.63 \\
& 3 & 212 & 2,246 & 12.00 & 440 & 33.24 \\
& 4 & 178 & 1,473 & 7.90 & 437 & 33.75 \\
& 5 & 40 & 155 & 0.80 & 450 & 28.39 \\
& 129 & 129 & 0.70 & 498 & 80.01 \\
Fancy & 61 & 220 & 1.20 & 470 & 51.16 \\
Choice & 17 & 96 & 0.50 & 468 & 51.20 \\
Good & 4 & 11 & 0.10 & 397 & 35.87 \\
& Standard & 40 & 0.20 & 430 & 42.85 \\
Short & 10 & 6,842 & 44.80 & 453 & 28.43 \\
& 1 & 523 & 4,691 & 30.74 & 422 & 27.85 \\
2 & 347 & 2,603 & 17.05 & 422 & 24.86 \\
3 & 252 & 848 & 5.55 & 407 & 24.85 \\
& 4 & 105 & 101 & 0.66 & 388 & 19.70 \\
& 5 & 29 & 33 & 0.22 & 471 & 43.39 \\
& Fancy & 33 & 27 & 0.18 & 466 & 38.06 \\
& Choice & 32 & 2 & 0.01 & 357 & 35.93 \\
Good & 14 & 8 & 0.05 & 408 & 35.08 \\
\hline Standard & 2 & & & &
\end{tabular}


Appendix D

Table 3

Means for Sale Place $\times$ Breed for Calves Included in This Analysis

\begin{tabular}{clrrrrr}
\hline $\begin{array}{c}\text { Sale } \\
\text { Place Code }\end{array}$ & Breed & $\begin{array}{c}\text { Number of } \\
\text { Observations }\end{array}$ & $\begin{array}{c}\text { Number } \\
\text { Head }\end{array}$ & $\begin{array}{c}\text { \% } \\
\text { Breed }\end{array}$ & $\begin{array}{c}\text { Av. } \\
\text { Wt. }\end{array}$ & $\begin{array}{c}\text { Av. } \\
\text { Price }\end{array}$ \\
\hline \multirow{2}{*}{201} & Angus & 108 & 1,322 & 54.30 & 451 & 33.13 \\
& BWF & 18 & 124 & 5.10 & 418 & 32.18 \\
& Charolais & 48 & 124 & 5.10 & 457 & 35.46 \\
& Hereford & 86 & 473 & 19.40 & 437 & 32.72 \\
& Angus Cross & 37 & 271 & 11.10 & 471 & 34.82 \\
& Hereford Cross & 17 & 43 & 1.76 & 473 & 33.01 \\
& MBRD & 2 & 2 & 0.10 & 480 & 27.37 \\
& Shorthorn & 1 & 1 & 0.04 & 540 & 42.50 \\
& Other Crosses & 18 & 76 & 3.10 & 433 & 27.26 \\
& Angus & 42 & 1,286 & 23.7 & 472 & 34.49 \\
& Hereford & 41 & 1,333 & 24.6 & 463 & 34.46 \\
& Angus Cross & 12 & 482 & 8.9 & 460 & 37.87 \\
& Hereford Cross & 51 & 1,888 & 34.8 & 462 & 34.45 \\
& Shorthorn & 5 & 35 & 0.6 & 477 & 36.90 \\
& Other Crosses & 25 & 399 & 7.4 & 456 & 32.07 \\
& Angus & 70 & 1,252 & 26.0 & 454 & 34.08 \\
& BWF & 89 & 858 & 17.8 & 446 & 33.06 \\
& Hereford & 86 & 1,695 & 35.2 & 447 & 32.64 \\
& Angus Cross & 1 & 38 & 0.8 & 358 & 26.50 \\
& Hereford Cross & 32 & 142 & 3.0 & 477 & 30.13 \\
& MBRD & 21 & 108 & 2.2 & 433 & 28.08 \\
& Char & 22 & 481 & 10.0 & 447 & 34.04 \\
& Other Crosses & & 229 & 4.8 & 467 & 36.52
\end{tabular}

(continued on next page) 
Appendix D

Table 3 (continued)

Means for Sale Place $\times$ Breed for Calves Included in This Analysis

\begin{tabular}{|c|c|c|c|c|c|c|}
\hline $\begin{array}{c}\text { Sale } \\
\text { Place Code }\end{array}$ & Breed & $\begin{array}{c}\text { Number of } \\
\text { Observations }\end{array}$ & $\begin{array}{c}\text { Number } \\
\text { Head }\end{array}$ & $\begin{array}{c}\% \\
\text { Breed }\end{array}$ & $\begin{array}{l}\text { Av. } \\
\text { Wt. }\end{array}$ & $\begin{array}{l}\text { Av. } \\
\text { Price }\end{array}$ \\
\hline 204 & $\begin{array}{l}\text { Angus } \\
\text { Charolais } \\
\text { Hereford } \\
\text { Angus Cross } \\
\text { Char } \\
\text { Hereford Cross } \\
\text { MBRD } \\
\text { Shorthorn } \\
\text { Other Crosses }\end{array}$ & $\begin{array}{r}81 \\
58 \\
179 \\
85 \\
17 \\
39 \\
114 \\
11 \\
25\end{array}$ & $\begin{array}{r}583 \\
430 \\
2,836 \\
904 \\
152 \\
189 \\
209 \\
16 \\
182\end{array}$ & $\begin{array}{r}10.6 \\
7.8 \\
51.6 \\
16.4 \\
2.8 \\
3.4 \\
3.8 \\
0.3 \\
3.3\end{array}$ & $\begin{array}{l}459 \\
444 \\
442 \\
440 \\
438 \\
469 \\
501 \\
462 \\
466\end{array}$ & $\begin{array}{l}47.33 \\
40.79 \\
39.66 \\
32.35 \\
28.55 \\
48.76 \\
70.49 \\
44.18 \\
41.88\end{array}$ \\
\hline 205 & $\begin{array}{l}\text { Angus } \\
\text { Charolais } \\
\text { Hereford } \\
\text { Angus Cross } \\
\text { Hereford Cross } \\
\text { MBRD } \\
\text { Other Crosses }\end{array}$ & $\begin{array}{r}48 \\
35 \\
88 \\
37 \\
7 \\
15 \\
12\end{array}$ & $\begin{array}{r}564 \\
725 \\
1,154 \\
393 \\
13 \\
23 \\
20\end{array}$ & $\begin{array}{r}19.5 \\
25.1 \\
39.9 \\
13.6 \\
0.4 \\
0.8 \\
0.7\end{array}$ & $\begin{array}{l}428 \\
437 \\
435 \\
425 \\
473 \\
467 \\
471\end{array}$ & $\begin{array}{l}28.62 \\
30.36 \\
35.41 \\
32.36 \\
28.11 \\
36.97 \\
29.85\end{array}$ \\
\hline 206 & $\begin{array}{l}\text { Angus } \\
\text { Charolais } \\
\text { Hereford } \\
\text { Angus Cross } \\
\text { Hereford Cross } \\
\text { MBRD } \\
\text { Shorthorn } \\
\text { Other Crosses }\end{array}$ & $\begin{array}{r}110 \\
79 \\
132 \\
116 \\
1 \\
6 \\
5 \\
79\end{array}$ & $\begin{array}{r}1,237 \\
544 \\
2,606 \\
1,045 \\
1 \\
9 \\
11 \\
278\end{array}$ & $\begin{array}{c}21.6 \\
9.5 \\
45.5 \\
18.2 \\
0.02 \\
0.16 \\
0.2 \\
4.8\end{array}$ & $\begin{array}{l}468 \\
467 \\
457 \\
474 \\
565 \\
499 \\
453 \\
469\end{array}$ & $\begin{array}{l}32.74 \\
34.46 \\
32.38 \\
33.81 \\
50.50 \\
26.83 \\
30.95 \\
31.14\end{array}$ \\
\hline
\end{tabular}


Hereford

Angus Cross

Hereford Cross

MBRD

Shorthorn

Other Crosses

79
63
100
19
15

79
63

63

5

1

Angus

BWF

29

208

Hereford

Char

MBRD

Shorthorn

Other Crosses

711
437
1,561
14
292
35
6
288

21.3
13.1

13.1
46.7

0.4

8.7
1.0

0.2

8.6

241

11.5

10.5
8.0

220

41.3

865

41.3
8.3

173

19.7

$5-0.7$

0.2
0.5

BWF

Char

MBRD

Shorthorn

Other Crosses

11

257

23.4

68
232

6.2

21.1

0.3

537

49.0

3.9

9.1

BWF

24

56

340

55.3

23.5

Charolais

145

23.5
7.8

$\begin{array}{ll}1 & 0.2 \\ 1 & 0.2\end{array}$

$\begin{array}{ll}1 & 0.2 \\ 1 & 0.2\end{array}$

$\begin{array}{ll}417 & 30.99 \\ 446 & 31.80 \\ 425 & 31.07 \\ 389 & 30.00 \\ 419 & 28.87 \\ 452 & 29.58 \\ 485 & 22.00 \\ 447 & 36.22 \\ 421 & 27.67 \\ 435 & 31.19 \\ 450 & 28.24 \\ 437 & 31.72 \\ 460 & 36.78 \\ 437 & 33.22 \\ 426 & 32.75 \\ 465 & 34.50 \\ 449 & 31.52 \\ 410 & 30.55 \\ 424 & 31.29 \\ 408 & 33.75 \\ 435 & 30.94 \\ 433 & 23.75 \\ 415 & 30.50 \\ 438 & 33.55 \\ 455 & 33.13 \\ 422 & 29.39 \\ 435 & 30.00 \\ 445 & 27.50\end{array}$

Shorthorn

Other Crosses

27.50 


\section{Appendix D}

\section{Table 4}

Means for Breed $\times$ Sex for Calves Included in This

Analysis

\begin{tabular}{llrrrrr}
\hline Breed & Sex & $\begin{array}{c}\text { Number of } \\
\text { Observations }\end{array}$ & $\begin{array}{r}\text { Number } \\
\text { Head }\end{array}$ & $\begin{array}{r}\% \text { in } \\
\text { Sex }\end{array}$ & $\begin{array}{c}\text { Av. } \\
\text { Wt. }\end{array}$ & $\begin{array}{c}\text { Av. } \\
\text { Price }\end{array}$ \\
\hline Angus & Steer & 331 & 4,045 & 56.0 & 460 & 39.38 \\
& Heifer & 243 & 3,175 & 44.0 & 435 & 27.18 \\
BWF & Steer & 112 & 762 & 50.3 & 455 & 36.72 \\
& Heifer & 112 & 753 & 49.7 & 422 & 27.27 \\
Chr & Steer & 192 & 1,204 & 49.6 & 463 & 38.14 \\
& Heifer & 147 & 1,223 & 50.4 & 436 & 28.27 \\
Hereford & Steer & 480 & 7,170 & 55.7 & 452 & 38.97 \\
& Heifer & 342 & 5,693 & 44.3 & 427 & 27.69 \\
Angus & Steer & 159 & 1,631 & 51.8 & 470 & 37.77 \\
Cross & Heifer & 130 & 1,516 & 48.2 & 439 & 28.17 \\
Char & Steer & 95 & 592 & 58.1 & 449 & 35.48 \\
& Heifer & 68 & 427 & 41.9 & 436 & 26.92 \\
Hereford- & Steer & 83 & 1,243 & 48.4 & 478 & 43.51 \\
Cross & Heifer & 83 & 1,325 & 51.6 & 449 & 28.54 \\
MBRD & Steer & 178 & 629 & 58.3 & 479 & 56.50 \\
& Heifer & 110 & 449 & 41.7 & 437 & 31.25 \\
Shorthorn & Steer & 24 & 55 & 70.5 & 451 & 39.36 \\
& Heifer & 6 & 23 & 29.5 & 480 & 28.91 \\
Other & Steer & 176 & 1,345 & 66.5 & 461 & 36.70 \\
Crosses & Heifer & 102 & 676 & 33.5 & 443 & 26.05 \\
\hline
\end{tabular}




\section{Appendix D}

Table 5

Means for Sale Place $\times$ Sex for Calves Included in

This Analysis

\begin{tabular}{llcrrrr}
\hline $\begin{array}{l}\text { Sale } \\
\text { Place Code }\end{array}$ & Sex & $\begin{array}{c}\text { Number of } \\
\text { Observations }\end{array}$ & $\begin{array}{c}\text { Number } \\
\text { Head }\end{array}$ & $\begin{array}{c}\text { Sex } \\
\text { Sex }\end{array}$ & $\begin{array}{c}\text { Av. } \\
\text { Wt. }\end{array}$ & $\begin{array}{c}\text { Av. } \\
\text { Price }\end{array}$ \\
\hline 201 & Steer & 199 & 1,380 & 56.6 & 462 & 38.93 \\
& Heifer & 136 & 1,056 & 43.4 & 430 & 24.73 \\
202 & Steer & 97 & 2,944 & 54.3 & 470 & 38.74 \\
& Heifer & 79 & 2,479 & 45.7 & 455 & 29.12 \\
& Steer & 210 & 2,608 & 54.2 & 462 & 36.58 \\
204 & Heifer & 179 & 2,204 & 45.8 & 437 & 27.63 \\
& Steer & 387 & 3,244 & 59.0 & 469 & 53.21 \\
205 & Heifer & 222 & 2,257 & 41.0 & 440 & 33.39 \\
& Steer & 150 & 1,553 & 53.7 & 453 & 36.90 \\
206 & Heifer & 112 & 1,339 & 46.3 & 416 & 26.17 \\
& Steer & 317 & 3,045 & 53.1 & 476 & 36.83 \\
207 & Heifer & 211 & 2,686 & 49.9 & 454 & 26.87 \\
& Steer & 161 & 1,778 & 53.5 & 440 & 35.26 \\
208 & Heifer & 147 & 1,608 & 47.5 & 420 & 27.27 \\
& Steer & 138 & 1,116 & 53.3 & 447 & 35.38 \\
209 & Heifer & 119 & 978 & 46.7 & 430 & 26.93 \\
& Steer & 105 & 689 & 62.8 & 443 & 35.45 \\
210 & Heifer & 85 & 408 & 37.2 & 420 & 25.86 \\
& Steer & 68 & 370 & 60.2 & 448 & 35.50 \\
& Heifer & 53 & 245 & 39.8 & 416 & 26.03 \\
\hline
\end{tabular}


Appendix D

Table 6

Means for Breed $\times$ Grade

\begin{tabular}{|c|c|c|c|c|c|c|}
\hline Breed & Grade & $\begin{array}{c}\text { Number of } \\
\text { Observations }\end{array}$ & $\begin{array}{c}\text { Number } \\
\text { Head }\end{array}$ & $\begin{array}{l}\% \text { in } \\
\text { Grade }\end{array}$ & $\begin{array}{l}\text { Average } \\
\text { Weight }\end{array}$ & $\begin{array}{l}\text { Average } \\
\text { Price }\end{array}$ \\
\hline Angus & $\begin{array}{r}1 \\
2 \\
3 \\
4 \\
5 \\
\text { Fancy } \\
\text { Choice } \\
\text { Good } \\
\text { Short }\end{array}$ & $\begin{array}{r}196 \\
168 \\
93 \\
69 \\
15 \\
15 \\
10 \\
4 \\
4\end{array}$ & $\begin{array}{r}2,363 \\
3,058 \\
856 \\
827 \\
40 \\
15 \\
27 \\
16 \\
18\end{array}$ & $\begin{array}{r}32.70 \\
42.30 \\
11.90 \\
11.50 \\
0.60 \\
0.20 \\
0.40 \\
0.20 \\
0.20\end{array}$ & $\begin{array}{l}466 \\
440 \\
438 \\
422 \\
477 \\
488 \\
461 \\
437 \\
448\end{array}$ & $\begin{array}{l}33.82 \\
33.62 \\
29.23 \\
30.63 \\
23.68 \\
93.53 \\
45.20 \\
40.50 \\
39.12\end{array}$ \\
\hline BWF & $\begin{array}{l}1 \\
2 \\
3 \\
4 \\
5\end{array}$ & $\begin{array}{r}102 \\
61 \\
49 \\
10 \\
2\end{array}$ & $\begin{array}{r}831 \\
403 \\
209 \\
68 \\
4\end{array}$ & $\begin{array}{r}54.80 \\
26.60 \\
13.80 \\
4.50 \\
0.30\end{array}$ & $\begin{array}{l}464 \\
417 \\
424 \\
380 \\
480\end{array}$ & $\begin{array}{l}33.77 \\
33.00 \\
27.70 \\
31.05 \\
21.00\end{array}$ \\
\hline Charolais & $\begin{array}{r}1 \\
2 \\
3 \\
4 \\
5 \\
\text { Fancy } \\
\text { Choice } \\
\text { Good } \\
\text { Standard } \\
\text { Short }\end{array}$ & $\begin{array}{r}141 \\
70 \\
69 \\
24 \\
5 \\
11 \\
11 \\
4 \\
1 \\
3\end{array}$ & $\begin{array}{r}1,534 \\
398 \\
368 \\
40 \\
15 \\
11 \\
42 \\
12 \\
1 \\
6\end{array}$ & $\begin{array}{r}63.20 \\
16.40 \\
15.20 \\
1.65 \\
0.61 \\
0.50 \\
1.70 \\
0.50 \\
0.04 \\
0.25\end{array}$ & $\begin{array}{l}478 \\
439 \\
428 \\
424 \\
370 \\
460 \\
458 \\
411 \\
372 \\
412\end{array}$ & $\begin{array}{l}33.68 \\
33.80 \\
29.87 \\
31.43 \\
23.15 \\
56.27 \\
45.13 \\
39.75 \\
36.50 \\
40.83\end{array}$ \\
\hline Hereford & $\begin{array}{r}1 \\
2 \\
3 \\
4 \\
5 \\
\text { Fancy } \\
\text { Choice } \\
\text { Good } \\
\text { Standard } \\
\text { Short }\end{array}$ & $\begin{array}{r}269 \\
204 \\
150 \\
95 \\
25 \\
44 \\
21 \\
8 \\
2 \\
4\end{array}$ & $\begin{array}{r}5,553 \\
4,268 \\
1,988 \\
769 \\
69 \\
44 \\
104 \\
44 \\
5 \\
19\end{array}$ & $\begin{array}{r}43.20 \\
33.20 \\
15.40 \\
6.00 \\
0.53 \\
0.34 \\
0.81 \\
0.34 \\
0.04 \\
0.15\end{array}$ & $\begin{array}{l}459 \\
438 \\
430 \\
427 \\
401 \\
461 \\
440 \\
415 \\
371 \\
418\end{array}$ & $\begin{array}{l}34.70 \\
33.17 \\
29.81 \\
29.83 \\
26.20 \\
58.38 \\
47.05 \\
40.87 \\
35.50 \\
39.37\end{array}$ \\
\hline $\begin{array}{l}\text { Angus } \\
\text { Cross }\end{array}$ & $\begin{array}{r}1 \\
2 \\
3 \\
4 \\
5 \\
\text { Fancy }\end{array}$ & $\begin{array}{r}118 \\
89 \\
45 \\
28 \\
7 \\
2\end{array}$ & $\begin{array}{r}1,487 \\
983 \\
370 \\
289 \\
16 \\
2\end{array}$ & $\begin{array}{r}47.20 \\
31.20 \\
11.80 \\
9.20 \\
0.50 \\
0.10\end{array}$ & $\begin{array}{l}471 \\
456 \\
430 \\
441 \\
461 \\
392\end{array}$ & $\begin{array}{l}34.95 \\
35.00 \\
30.22 \\
29.62 \\
22.21 \\
42.50\end{array}$ \\
\hline
\end{tabular}




\section{Appendix D \\ Table 6 (continued)}

Means for Breed $\times$ Grade

\begin{tabular}{|c|c|c|c|c|c|c|}
\hline Breed & Grade & $\begin{array}{c}\text { Number of } \\
\text { Observations }\end{array}$ & $\begin{array}{c}\text { Number } \\
\text { Head }\end{array}$ & $\begin{array}{l}\% \text { in } \\
\text { Grade }\end{array}$ & $\begin{array}{l}\text { Average } \\
\text { Weight }\end{array}$ & $\begin{array}{l}\text { Average } \\
\text { Price }\end{array}$ \\
\hline Char & $\begin{array}{r}1 \\
2 \\
3 \\
4 \\
5 \\
\text { Fancy }\end{array}$ & $\begin{array}{r}72 \\
37 \\
37 \\
12 \\
3 \\
2\end{array}$ & $\begin{array}{r}704 \\
132 \\
140 \\
37 \\
4 \\
2\end{array}$ & $\begin{array}{r}69.10 \\
13.00 \\
13.70 \\
3.60 \\
0.40 \\
0.20\end{array}$ & $\begin{array}{l}456 \\
445 \\
422 \\
439 \\
370 \\
522\end{array}$ & $\begin{array}{l}32.85 \\
32.33 \\
29.90 \\
31.35 \\
26.67 \\
38.75\end{array}$ \\
\hline $\begin{array}{l}\text { Other } \\
\text { Crosses }\end{array}$ & $\begin{array}{r}1 \\
2 \\
3 \\
4 \\
5 \\
\text { Fancy }\end{array}$ & $\begin{array}{r}125 \\
65 \\
64 \\
16 \\
6 \\
2\end{array}$ & $\begin{array}{r}1,113 \\
439 \\
302 \\
109 \\
56 \\
2\end{array}$ & $\begin{array}{r}55.10 \\
21.70 \\
14.90 \\
5.40 \\
2.80 \\
0.10\end{array}$ & $\begin{array}{l}477 \\
434 \\
439 \\
443 \\
386 \\
510\end{array}$ & $\begin{array}{l}34.15 \\
33.12 \\
30.01 \\
32.31 \\
25.79 \\
50.50\end{array}$ \\
\hline $\begin{array}{l}\text { Hereford- } \\
\text { Cross }\end{array}$ & $\begin{array}{r}1 \\
2 \\
3 \\
4 \\
5 \\
\text { Fancy } \\
\text { Choice } \\
\text { Good } \\
\text { Standard } \\
\text { Short }\end{array}$ & $\begin{array}{r}64 \\
32 \\
22 \\
8 \\
5 \\
13 \\
13 \\
5 \\
1 \\
3\end{array}$ & $\begin{array}{r}1,391 \\
506 \\
502 \\
42 \\
43 \\
13 \\
35 \\
24 \\
5 \\
7\end{array}$ & $\begin{array}{r}54.20 \\
19.70 \\
19.50 \\
1.60 \\
1.70 \\
0.50 \\
1.40 \\
0.90 \\
0.20 \\
0.30\end{array}$ & $\begin{array}{l}482 \\
440 \\
442 \\
430 \\
434 \\
529 \\
455 \\
454 \\
415 \\
411\end{array}$ & $\begin{array}{l}34.92 \\
32.10 \\
29.23 \\
27.47 \\
23.75 \\
64.50 \\
42.23 \\
38.60 \\
37.50 \\
39.50\end{array}$ \\
\hline $\begin{array}{l}\text { Mixed } \\
\text { Straight- } \\
\text { breds }\end{array}$ & $\begin{array}{r}1 \\
2 \\
3 \\
4 \\
\text { Fancy } \\
\text { Choice } \\
\text { Good } \\
\text { Standard } \\
\text { Short }\end{array}$ & $\begin{array}{r}71 \\
53 \\
30 \\
18 \\
70 \\
34 \\
9 \\
2 \\
1\end{array}$ & $\begin{array}{r}276 \\
393 \\
103 \\
95 \\
70 \\
111 \\
24 \\
2 \\
4\end{array}$ & $\begin{array}{r}25.60 \\
36.40 \\
9.60 \\
8.80 \\
6.50 \\
10.30 \\
2.20 \\
0.20 \\
0.40\end{array}$ & $\begin{array}{l}464 \\
407 \\
435 \\
405 \\
516 \\
495 \\
491 \\
387 \\
390\end{array}$ & $\begin{array}{l}31.38 \\
31.58 \\
28.23 \\
31.54 \\
84.19 \\
49.35 \\
54.72 \\
35.00 \\
44.00\end{array}$ \\
\hline Shorthorn & $\begin{array}{r}1 \\
2 \\
3 \\
4 \\
\text { Fancy } \\
\text { Choice } \\
\text { Good } \\
\text { Short }\end{array}$ & $\begin{array}{l}7 \\
7 \\
5 \\
2 \\
3 \\
4 \\
1 \\
1\end{array}$ & $\begin{array}{r}18 \\
33 \\
11 \\
3 \\
3 \\
6 \\
3 \\
1\end{array}$ & \begin{tabular}{r|}
23.10 \\
42.30 \\
14.10 \\
3.80 \\
3.80 \\
7.70 \\
3.80 \\
1.30
\end{tabular} & $\begin{array}{l}441 \\
452 \\
467 \\
465 \\
478 \\
487 \\
478 \\
425\end{array}$ & $\begin{array}{l}36.28 \\
32.46 \\
29.80 \\
32.50 \\
40.00 \\
43.87 \\
40.00 \\
40.00\end{array}$ \\
\hline
\end{tabular}




\section{Appendix D}

\section{Table 7}

Means for Grade $\times$ Year for Calves Included in This Analysis

\begin{tabular}{lrcrcc}
\hline \hline Year & Grade & $\begin{array}{c}\text { Number of } \\
\text { Observations }\end{array}$ & $\begin{array}{c}\text { Number } \\
\text { Head }\end{array}$ & $\begin{array}{c}\text { Average } \\
\text { Weight }\end{array}$ & $\begin{array}{c}\text { Average } \\
\text { Price }\end{array}$ \\
\hline 1976 & 1 & 571 & 7,411 & 466 & 31.23 \\
& 2 & 359 & 4,950 & 438 & 30.91 \\
& 3 & 260 & 2,366 & 431 & 27.42 \\
& 4 & 138 & 1,114 & 427 & 28.11 \\
& 5 & 34 & 136 & 436 & 23.15 \\
1977 & 17 & 17 & 467 & 47.85 \\
& Fancy & 594 & 7,859 & 469 & 36.70 \\
& 1 & 5,663 & 436 & 35.34 \\
& 3 & 304 & 2,483 & 433 & 31.27 \\
& 4 & 145 & 1,207 & 424 & 32.68 \\
5 & 35 & 120 & 412 & 26.27 \\
& Fancy & 145 & 145 & 496 & 75.45 \\
& Choice & 93 & 325 & 469 & 46.65 \\
Good & 31 & 123 & 448 & 44.31 \\
& 6 & 13 & 469 & 36.70 \\
& Standard & 6 & 55 & 422 & 39.94 \\
\hline
\end{tabular}


Blank Page in Original Bulletin 
